\title{
Clinico-epidemiological profile of confirmed swine flu (H1N1) cases admitted at an infectious disease hospital in Kolkata, India
}

\author{
Jadab Chandra Sardar ${ }^{1}$, Arkaprabha Sau ${ }^{1}$, Pankaj Kumar Mandal ${ }^{2}$
}

\begin{abstract}
${ }^{1}$ Department of Community Medicine, R. G. Kar Medical College and Hospital, Kolkata, West Bengal, India
${ }^{2}$ Department of Community Medicine, Beliaghata ID and BG Hospital, Kolkata, West Bengal, India
\end{abstract}

Received: 27 June 2016

Accepted: 13 July 2016

\section{*Correspondence:}

Dr. Arkaprabha Sau,

E-mail: arka.doctor@gmail.com

Copyright: (C) the author(s), publisher and licensee Medip Academy. This is an open-access article distributed under the terms of the Creative Commons Attribution Non-Commercial License, which permits unrestricted non-commercial use, distribution, and reproduction in any medium, provided the original work is properly cited.

\begin{abstract}
Background: Swine flu is an acute infection of respiratory tract, caused by swine origin influenza A (H1N1) virus. Antigenic drift and shift of this virus is responsible for epidemic or pandemic in different parts of the world from time to time. Last pandemic started in 2009 at Mexico and USA, and spread globally with in a very short period of time. Post pandemic resurgence was noticed in various parts of India from 2010 to 2015.

Methods: A record based descriptive study was carried out among the 89 confirmed swine flu (H1N1) cases admitted at Beliaghata ID and BG Hospital, Kolkata during last post pandemic resurgence in India between February 2015 to March 2015.

Results: Among 89 confirmed swine flu cases $52.81 \%$ were male and $47.19 \%$ were female. Mean $( \pm$ Standard Deviation) age was $38( \pm 18)$ yrs. Mean ( \pm Standard Deviation) duration of hospital stay was $6.5( \pm 1.7)$ days. Among the admitted patients, 84 patients were discharged from the hospital but 5 patients succumbed to their illness. $95.51 \%$ patient presented with the chief complaint of fever. Among the admitted cases, $21.34 \%$ had either history of travel to swine flu $(\mathrm{H} 1 \mathrm{~N} 1)$ infected area or contact with swine flu infected patients. There was a statistically significant association between outcome (death / discharge) and co-morbid conditions, (P value-0.047, $\alpha-5 \%, \mathrm{df}-1$ ).

Conclusions: This study will help clinicians and public health specialist to understand the clinico-epidemiological profile of swine flu (H1N1) cases to diagnose, treat and to develop preventive strategies in future.
\end{abstract}

Keywords: Clinico-epidemiological profile, Influenza, H1N1, Swine flu

\section{INTRODUCTION}

Influenza is an acute infection of respiratory tract, caused by influenza virus. This virus is under the family of Orthomyxoviridae. There are three subtype of this virus i.e. Type A, Type B and Type C. Among them Influenza A virus has 2 distinct antigens on its surface, namely the haemagglutinin $(\mathrm{H})$ and the neuraminidase $(\mathrm{N})$. This influenza virus has a unique property of frequent major and minor antigenic variation, called antigenic Shift and Drift respectively. ${ }^{1}$ This antigenic variation is responsible for major epidemic or pandemic affecting most or all age group. Among three antigenically distinct subtype of this virus, swine origin influenza A (H1N1) was first reported from Mexico and United States of America in April 2009 and since then it spread worldwide with in a very short period of time and resulted in a global pandemic of this century. ${ }^{2}$ In India that pandemic began on May $2009 .^{3}$ There were 45101 laboratory confirmed cases and 2679 deaths in India till October 2010. ${ }^{4}$ In West Bengal there were 265 cases and 4 deaths during this pandemic. ${ }^{5}$ Post pandemic resurgence was noticed in various part of the country from 2010 to 2015. Last resurgence was observed in several Indian states between December 2014 to March 2015. During this period there were 30000 
cases and 2000 deaths countrywide. ${ }^{3}$ Influenza cases infected by swine origin influenza A (H1N1) virus, was also reported from West Bengal from the month of February to March 2015 at Beliaghata ID and BG Hospital, a tertiary care hospital in Kolkata, West Bengal, India. ${ }^{6}$ During the last resurgence in 2015, this hospital was acted as a referral center for H1N1 infected persons. H1N1 cases were confirmed by real time reverse transcriptase polymerase chain reaction (RT-PCR) on throat swab.

Clinico-epidemiological profile of the H1N1 infected patients varies from place to place and from time to time. ${ }^{7}$ This study will help to understand the clinicoepidemiological profile of the confirmed H1N1 cases during the last post pandemic resurgence in 2015 in Kolkata.

\section{METHODS}

Study design: Record based descriptive study.

Study setting: The study was conducted at Beliaghata I.D and B.G Hospital, Kolkata, West Bengal, India.

Study subjects: All the confirmed swine flu (H1N1) cases admitted at the hospital during the last resurgence in 2015, i.e. from the month of February 2015 to march 2015. First and last confirmed swine flu case was admitted on 19.02.2015 and 30.03.2015 respectively. Total 89 patients were admitted during this period.

Case Definition of Swine flu in Humans: ${ }^{8}$

\section{A suspected case of swine influenza $A$ (H1N1) virus infection:}

Person with acute febrile respiratory illness (fever $\geq 38^{0}$ C) with onset within 7 days of close contact with a person who is a confirmed case of swine influenza A (H1N1) virus infection, or within 7 days of travel to areas where there are one or more confirmed swine influenza A (H1N1) cases, or resides in a community where there are one or more confirmed swine influenza cases.

\section{A probable case of swine influenza A (H1N1) virus infection:}

A person with an acute febrile respiratory illness who is positive for influenza $\mathrm{A}$, but un-subtypable for $\mathrm{H} 1$ and H3 by influenza RT-PCR or reagents used to detect seasonal influenza virus infection, or is positive for influenza $A$ by an influenza rapid test or an influenza immunofluorescence assay (IFA) plus meets criteria for a suspected case, or individual with a clinically compatible illness who died of an unexplained acute respiratory illness who is considered to be epidemiologically linked to a probable or confirmed case.

\section{A confirmed case of swine influenza A (H1N1) virus infection:}

A person with an acute febrile respiratory illness with laboratory confirmed swine influenza A (H1N1) virus infection at WHO approved laboratories by one or more of the following tests: Real Time PCR or Viral culture or Four-fold rise in swine influenza A (H1N1) virus specific neutralizing antibodies.

\section{Study period: From 01.05.2015 to 31.05.2015.}

Sampling design: No sampling technique was followed. Record of all the swine flu (H1N1) confirmed cases, admitted at the hospital during the period from 19.02.15 to 30.03 .15 , were included in the study.

Study tools: Indoor Bed Head Tickets of the patients.

Data collection: Required data were collected from indoor Bed Head Tickets of the study population.

Data analysis: Statistical analysis was done using SPSS version 20 software. $\mathrm{P}$ value less than 0.05 was considered to be statistically significant.

\section{RESULTS}

Total 89 confirmed swine flu (H1N1) cases were admitted at the hospital during that resurgence period from 19.02.15 to 30.03.15. Among them 47 (52.81\%) were male and $42(47.19 \%)$ were female. Minimum and maximum age of the admitted patients were 2 yrs. and 85 yrs. respectively. Mean ( \pm Standard Deviation) age was 38 $( \pm 18)$ yrs. Minimum and maximum duration of hospital stay was 3 days and 10 days respectively. Mean ( \pm Standard Deviation) duration of hospital stay was 6.5 $( \pm 1.7)$ days. Among the admitted patients, $84(94.38 \%)$ patients were discharged from the hospital but $5(5.62 \%)$ patients succumbed to their illness. $95.51 \%$ patient presented with the chief complaint of fever followed by cough and cold by $51.68 \%$ of the patients. During admission respiratory distress along with fever was complained by $44.94 \%$ of patients (Distribution of presenting symptoms summarized in Table 1).

First confirmed swine flu (H1N1) case was admitted on 19.02.2015 and last case was admitted on 30.03.2015. Maximum no of patients (29) admitted at $4^{\text {th }}$ week i.e. from 12.03.2015 to 18.03.2015 (Figure 1). Distribution of admission in various weeks starting from 19.02.2015 to 30.03.2015 were presented in Fig.1. Most of the admitted patients were in age group of 20-30 yrs. (28.10\%) followed by $30-40$ yrs. (15.73\%) (Table 2). Age and sex distribution of the admitted patients were tabulated in Table-2. Among the admitted patients, $21.34 \%$ had either history of travel to swine flu (H1N1) infected area or contact with swine flu infected patients. 
Among the admitted swine flu cases 34 (38.20\%) were suffering from one or more co-morbid conditions. Among them $27(30.33 \%)$ patients were suffering from Diabetes Mellitus, followed by 24 (26.97\%) from Hypertension, 19 $(21.35 \%)$ from Ischemic Heart Disease, 18 (20.22\%) from Chronic Obstructive Pulmonary Disease (COPD)/ Bronchial Asthma and 7 (7.87\%) patients from Chronic Renal Failure (Table 3). Twenty (22.47\%) patients were suffering from other diseases like Hypothyroidism, Hepatitis or Typhoid fever (Table 3).

Among 5 patients, who died of $\mathrm{H} 1 \mathrm{~N} 1$ infection, 4 patients also suffered from some form of co-morbid condition. Table 4 shows that there was a statistically significant association between outcome (death $/$ discharge) and co-morbid conditions, ( $\mathrm{P}$ value-0.047, $\alpha$ $5 \%$, df-1).
Table 1: Summary table of presenting symptoms of the admitted swine flu cases $(\mathrm{N}=89) *$.

\begin{tabular}{|lll|}
\hline Presenting symptoms & Frequency & $\%$ \\
\hline Fever & 85 & 95.51 \\
\hline Cough and cold & 46 & 51.68 \\
\hline Respiratory distress & 40 & 44.94 \\
\hline Sore throat & 16 & 17.97 \\
\hline Headache and body ache & 13 & 14.61 \\
\hline Running nose & 11 & 12.35 \\
\hline Rash & 6 & 6.74 \\
\hline $\begin{array}{l}\text { Others (vomiting, chest pain, } \\
\text { haemoptysis) }\end{array}$ & 12 & 13.48 \\
\hline
\end{tabular}

*Multiple Responses.

Table 2: Age and sex wise distribution of the study population. (N=89).

\begin{tabular}{|lllllll|}
\hline Age Group & Male & & Female & & Total & \\
\hline Yrs. & Frequency & $\%$ & Frequency & $\%$ & Frequency & $\%$ \\
\hline $0-10$ & 1 & 1.12 & 2 & 2.25 & 3 & 3.37 \\
\hline $10-20$ & 5 & 5.62 & 4 & 4.49 & 9 & 10.11 \\
\hline $20-30$ & 15 & 16.85 & 10 & 11.25 & 25 & 28.10 \\
\hline $30-40$ & 2 & 2.25 & 12 & 13.48 & 14 & 15.73 \\
\hline $40-50$ & 8 & 8.99 & 4 & 4.49 & 12 & 13.48 \\
\hline $50-60$ & 8 & 8.99 & 4 & 4.49 & 12 & 13.48 \\
\hline$\geq 60$ & 8 & 8.99 & 6 & 6.74 & 14 & 15.73 \\
\hline Total & 47 & 52.81 & 42 & 47.19 & 89 & 100 \\
\hline
\end{tabular}

Table 3: Distribution of co-morbidity among the patients. $(\mathbf{n}=89) *$.

\begin{tabular}{|lll|}
\hline Co-morbidity & Frequency & $\%$ \\
\hline Copd / asthma & 18 & 20.22 \\
\hline Hypertension & 24 & 26.97 \\
\hline Diabetes mellitus & 27 & 30.33 \\
\hline Chronic renal failure & 7 & 7.87 \\
\hline Ischemic heart disease & 19 & 21.35 \\
\hline $\begin{array}{l}\text { Others } \\
\text { (hypothyroidism, } \\
\text { hepatitis, typhoid } \\
\text { fever) }\end{array}$ & 20 & 22.47 \\
\hline No co morbidity & 55 & 61.79 \\
\hline
\end{tabular}

*Multiple Responses

Table 4: Association of outcome with co morbidity. $(\mathrm{N}=\mathbf{8 9})$.

\begin{tabular}{|c|c|c|c|}
\hline \multirow{2}{*}{$\begin{array}{l}\text { Co- } \\
\text { morbidity }\end{array}$} & \multicolumn{2}{|c|}{ Outcome } & \multirow{2}{*}{ Significance } \\
\hline & Death & Discharge & \\
\hline Yes & 4 & 30 & \multirow{3}{*}{$\begin{array}{l}\text { Chi square } \\
\text { value- } 3.92 \\
\text { P value- } 0.047 \\
\text { degree of } \\
\text { freedom (df)-1 }\end{array}$} \\
\hline No & 1 & 54 & \\
\hline Total & 5 & 84 & \\
\hline
\end{tabular}

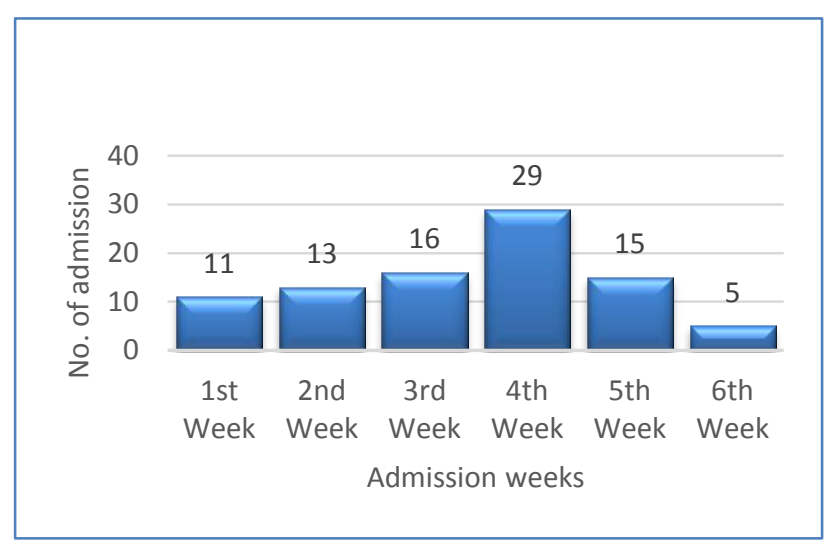

Figure 1: Bar diagram showing no. of admission from $1^{\text {st }}$ week to $6^{\text {th }}$ week.

\section{DISCUSSION}

In this study, it had been shown that, confirmed swine flu cases were admitted at Beleghata ID and BG hospital, Kolkata during the period from 19.02.15 to 30.03.15. Study conducted by KS Amaravathi et al observed that their cases were admitted between December 10, 2014 to May 11, 2015 at Osmania General Hospital, Hyderabad, Telangana, India. ${ }^{9}$ In our study, $52.81 \%$ of the admitted 
patients were male and remaining $47.19 \%$ were female. Study conducted by KS Amaravathi et al Asmita et al, Chudasama et al. ${ }^{9-11}$ also found almost equal distribution of male and female among their confirmed cases. Mean age ( \pm Standard Deviation) of the confirmed cases were $38( \pm 18)$ yrs. with a range of 2 yrs. to 85 yrs. Though study conducted by T Samra et. al. found mean age of the patients were 29 yrs. $^{12}$ Mean $( \pm$ Standard Deviation) duration of hospital stay was $6.5( \pm 1.7)$ days in this study. Major presenting complaints were fever, cough and cold, respiratory distress, sore throat, which are also similar with the other studies. ${ }^{9-11,13}$ Important co-morbidities like diabetes mellitus, hypertension, ischemic heart disease, COPD etc. were found to be similar with the other studies. $^{10,11}$ There was a statistically significant association between outcome of the admitted patients and co-morbid conditions. Study conducted by KS Amaravathi also identified co morbid conditions as a major decisive factors in relation to outcome of the disease. ${ }^{9}$ To conclude, it can be said that this study will help clinicians and public health specialist to understand the clinico-epidemiological profile of swine flu (H1N1) cases to diagnose, treat and to develop preventive strategies in future.

\section{CONCLUSION}

This study will help clinicians and public health specialist to understand the clinico-epidemiological profile of swine flu (H1N1) cases to diagnose, treat and to develop preventive strategies in future.

\section{ACKNOWLEDGEMENTS}

We are thankful to the Beliaghata ID and BG hospital authority for their kind and unconditional support.

Funding: No funding sources Conflict of interest: None declared

Ethical approval: The study was approved by the Institutional Ethics Committee

\section{REFERENCES}

1. Park K. Park's textbook of preventive and social medicine. 23 ed. Jabalpur: M/s Banarsidas Bhanot; 2015.

2. Dawood F, Jain S, Finelli L, Shaw M, Lindstrom S, Garten R, et al. Novel Swine-Origin Influenza A (H1N1) Virus Investigation Team. Emergence of a novel swine-origin influenza A (H1N1) virus in humans. N Engl J Med. 2009;360:2605-15.

3. Mishra B. 2015 resurgence of influenza a (H1N1) 09: Smoldering pandemic in India? Journal of global infectious diseases. 2015;7(2):56.

4. Mukherjee A, Roy T, Agrawal AS, Sarkar M, Lal R, Chakrabarti S, et al. Prevalence and epidemiology of pandemic H1N1 strains in hospitals of Eastern India. Journal of Public Health and Epidemiology. 2010;2(7):171-4.

5. Mondal PK, Sardar JC, Bhandari B. Clinical profile of H1N1 Influenza: a hospital based epidemiological study in Kolkata, India. Sudanese Journal of Public Health. 2013;8(1).

6. Dhawale S, Jayant S. Clinical profile, morbidity and mortality among swine flu (H1N1) infected patients: 2015 Gwalior, Madhya Pradesh pandemic, India. International Journal of Advances in Medicine. 2016;3(2):324-7.

7. Shrikhande S, Bhoyar S, Tenpe S, Deogade N. Epidemiology of pandemic H1N1 strains in a tertiary hospital of Maharashtra. Indian journal of public health. 2012;56(3):242.

8. Case Definition of Swine flu (H1N1) in Humans: Government of West Bengal, Health and Family Welfare Department,2015. Accessed 2015 May 1. Available at: http://www.wbhealth.gov.in/swine_influenza/revise d\%20guidelines/case\%20definition_h1n1.pdf.

9. Amaravathi KS, Sakuntala P, Sudarsi B, Manohar S, Nagamani R, Rao SR. Clinical profile and outcome of recent outbreak of influenza A H1N1 (swine flu) at a tertiary care center in Hyderabad, Telangana. Annals of Tropical Medicine and Public Health. 2015;8(6):267.

10. Mehta AA, Kumar VA, Nair SG, Joseph FK, Kumar G, Singh SK. Clinical profile of patients admitted with swine-origin influenza A (H1N1) virus infection: an experience from a tertiary care hospital. Journal of Clinical and Diagnostic Research. 2013;7(10):2227-30.

11. Chudasama RK, Patel UV, Verma PB, Amin CD, Savaria D, Ninama R, et al. Clinico-epidemiological features of the hospitalized patients with 2009 pandemic influenza A (H1N1) virus infection in Saurashtra region, India (September, 2009 to February, 2010). Lung India. 2011;28(1):11.

12. Samra T, Pawar M, Yadav A. One year of experience with H1N1 Infection: clinical observations from a tertiary care hospital in Northern India. Indian Journal of Community Medicine. 2011;36(3):241.

13. Puvanalingam A, Rajendiran C, Sivasubramanian K, Ragunanthanan S, Suresh S, Gopalakrishnan S. Case series study of the clinical profile of H1N1 swine flu influenza. J Assoc Physicians India. 2011;59:14-16.

Cite this article as: Sardar JC, Sau A, Mandal PK.

Clinico-epidemiological profile of confirmed swine flu (H1N1) cases admitted at an infectious disease hospital in Kolkata, India. Int $\mathbf{J}$ Community Med Public Health 2016;3: 2340-3. 